\title{
A New Game in Town: Disseminating Sports Content in a Net Neutrality-Less Era-The Potential Implications for the Post-Broadcasting World
}

\begin{abstract}
Mark Conrad*
The Federal Communications Commission's ("FCC") repeal of the net neutrality rules has implications for the consumers of program content found on broadband Internet service providers ("ISPs"). Under the former rule, such providers engage in discrimination by favoring some content over others or by using their broadband to speed up favored content or slow down less favored content (practices known as "throttling"). With the demise of net neutrality, ISPs have the power to control what viewers see and how they see it, with few resources to fight such decisions. One key category is sports. The end of net neutrality can have an adverse impact to sports streams, because of the high amounts of broadband space utilized and the rapid consolidation between sports content providers and ISPs. This article discusses the background of the powers of the FCC, the history of the net neutrality rules, the FCC's 2018 order repealing the rules, and the legal and political reactions to it. It concludes by raising a number of hypothetical situations where the lack of net neutrality can have an adverse impact for consumers of sports material.
\end{abstract}

After his stunning victory in the 2016 election, President Donald Trump pledged to steer the nation in a different course of conduct from that of his predecessor. $^{1}$ While his approach to governance and leadership have been considered unconventional, when it came to regulatory agency appointments, he has followed a more traditional Republican playbook of deregulation of

\footnotetext{
${ }^{1}$ At his Inauguration, President Trump made his views clear: "January 20th, 2017, will be remembered as the day the people became the rulers of this nation again. ... [the] American carnage stops right here and stops right now. ... From this day forward, a new vision will govern our land. From this moment on, it's going to be America first. ... America will start winning again, winning like never before." See Inaugural Address, President Donald J. Trump (Jan. 20, 2017) https://www. whitehouse.gov/briefings-statements/the-inaugural-address/

"Mark Conrad, JD, is an associate professor of law and ethics and director of the Sports Business Concentration in the Gabelli School of Business at Fordham University; email: conrad@fordham. $\underline{\text { edu }}$
} 
what is perceived as onerous governmental meddling in business. ${ }^{2}$ Many of his appointees have strong industry connections, ${ }^{3}$ and even those who are career politicians have acted quickly and decisively to further a pro-industry bent. ${ }^{4} \mathrm{~A}$ compelling example of this deregulatory thrust is found in the administration's telecommunications policy, through the action of the Republican-dominated Federal Communications Commission ("FCC").

Barely one month into his administration, the President appointed Ajit Pai to chair the $\mathrm{FCC}^{5}{ }^{5}$ the agency responsible for regulating broadcasting, cable, satellite, and broadband media. Since he took the helm of the commission, Pai has been the point person to lead the often-divided five-member commission in a very different direction from his Democratic predecessors. ${ }^{6}$ Pai has made no secret of his priorities - his strong pro-industry views recall the FCC mindset

\footnotetext{
2 See Demetri Sevastopulo, Sam Fleming, \& Barney Jopson, Trump Year One: Better Scorecard than Predicted, Financial Times (Dec. 17, 2017), https://www.ft.com/content/a8676fac-e34d-11e78b99-0191e45377ec (quoting Larry Sabato, a University of Virginia politics professor, who said, "Most people don't follow federal rulemaking, but Trump and company are deconstructing the regulatory system in much of government, from the environment to the internet to the financial world.")
}

3 One study found a very high number of career businesspeople as Cabinet secretaries at the time of inauguration. Only one third of the department heads in the Trump administration were people whose prior experience has been entirely in the public sector. His cabinet was top-heavy with businesspeople. Rex Tillerson, who served as Exxon Mobil's chairman and CEO, was nominated Secretary of State; hedge fund investor and Hollywood financier Steven Mnuchin, nominated as Treasury Secretary; Andrew Puzder, CEO of CKE Restaurants (which owns the Hardee's and Carl's Jr. chains), nominated as Labor Secretary; Wilbur Ross, a Wall Street veteran who invests in distressed companies, a nominee for Commerce Secretary; and Betsy DeVos, a billionaire philanthropist and school-voucher activist who was Trump's pick for Education Secretary. See Drew Desilver, Trump's Cabinet will be One of the Most Business-Heavy in U.S. history, Pew Research Center (Jan. 19, 2017), http://www.pewresearch.org/fact-tank/2017/01/19/trumps-cabinet-will-beone-of-most-business-heavy-in-u-s-history/

4 Just one example is Environmental Protection Agency head Scott Pruitt, whose agency reversed or sought to reverse 67 environmental regulations from Jan. 2017 - Jan. 2018. See Nadia Popovich, Livia Albeck-Ripka, \& Kendra Pierre-Louis, 67 Environmental Rules on the Way Out Under Trump, The New York Times (Jan. 31, 2018), https://www.nytimes.com/interactive/2017/10/05/climate/trump-environment-rules-reversed.html

\footnotetext{
5 See Ajit Pai, FCC Chairman, https://www.fcc.gov/about/leadership/ajit-pai

${ }_{6}$ To avoid excess partisanship, three of the commissioners are identified with the President's party and two from the opposition party. As of early 2018, the FCC consists of Chairman Pai, and commissioners Michael O'Rielly and Brendan Carr (the "Republican" members) and Mignon Clyburn and Jessica Rosenworcel (the "Democratic" members). Pai was nominated by President Obama in 2012 as one of the two "Republican" members. Prior to becoming a Commissioner, Chairman Pai served in the FCC's Office of General Counsel. Prior to his FCC service, he served as a clerk to a federal judge, as senior counsel to two U.S. Senators, and as a senior attorney in the Justice Department. He holds his undergraduate degree from Harvard and his law degree from the University of Chicago Law School. See Ajat Pai, FCC Chairman, https://www.fcc.gov/about/ leadership/ajit-pai
} 
of the Ronald Reagan and George W. Bush administrations. ${ }^{7}$ Pai did what he said he would - propose the deregulation of hot-button issues like net neutrality, broadcast ownership restrictions, auctioning spectrum, and easing rules on media mergers. ${ }^{8}$

Pai is no novice and he was not sent from the hinterlands to drain the swamp. $\mathrm{He}$ is an FCC pro. An attorney specializing in telecommunications law, Pai took the helm of the agency after being one of its staff members and then one of its five commissioners for the previous half-decade. ${ }^{9}$ As one press account noted, "he is very much a lifer when it comes to technology and communications issues." 10 Within a few months, Pai spearheaded Republican members of the FCC to relax various broadcast ownership rules, and sought to expedite development of a new generation of "super" high-definition televisions. ${ }^{11}$

\footnotetext{
7 In 1981, then FCC Chair Mark Fowler, who described television as a "toaster with pictures," presided over an FCC that significantly deregulated broadcast ownership rules and telephone regulations. He felt that the public interest should be determined by economic forces, rather than governmental policy. See Peter J. Boyer, Under Fowler, FCC Treated TV as Commerce, The New York Times (Jan. 19, 1987), https://www.nytimes.com/1987/01/19/arts/under-fowler-fcc-treated-tvas-commerce.html. A generation later, under George W. Bush administration FCC chairs Michael Powell and later Kevin Martin, the FCC sought deregulation of rules involving telephones, Internet, and broadcast ownership. However, both enforced rules against broadcast indecency more aggressively than past FCC administrations. See Steve Labaton, Powell to Step Down at F.C.C. After Pushing for Deregulation, The New York Times (Jan. 22, 2005). http://www.nytimes. com/2005/01/22/politics/powell-to-step-down-at-fcc-after-pushing-for-deregulation.html. See also John Dunbar, As FCC Chair Martin Resigns, He Leaves Controversial Legacy, CENTER FOR PubliC INTEGRITY (June 27, 2007), https://www.publicintegrity.org/2007/06/27/6618/fcc-chair-martin-re$\underline{\text { signs-he-leaves-controversial-legacy }}$
}

8 In a short span of several months, Chairman Pai and the Republican majority proposed to loosen media ownership rules, ease rules for joint newspaper/broadcast ownership and eliminate net neutrality. See Cecilia Kang, F.C.C. to Loosen Rules on Local Media Ownership, THE New York Times (Oct. 25, 2017), https://www.nytimes.com/2017/10/25/technology/fcc-media-ownership-rules.html

\footnotetext{
9 See n. 5.
}

10 Before coming to the FCC, Pai served in the FCC's Office of Legal Counsel, a legal clerk for a federal judge, senior counsel to two U.S. Senators and as senior attorney in Justice Department. See Larry Downes, Why Is The Media Smearing New FCC Chair Ajit Pai As The Enemy Of Net Neutrality?, Forbes (Jan. 24, 2017), https://www.forbes.com/sites/larrydownes/2017/01/24/why-isthe-media-smearing-new-fcc-chair-ajit-pai-as-the-enemy-of-net-neutrality/ $\# 453675 \mathrm{~d} 2438 \mathrm{e}$

11 See. n. 8. In November 2017, Chairman Pai spearheaded the FCC, in a party-line 3-2 vote, to propose the abolition of the newspaper-broadcast cross-ownership rules (which limit newspaper ownership of broadcast stations in its market), radio-TV cross-ownership rules that had limited combinations of radio and television stations in the same market, and to limit restrictions on combinations of television stations in the same market. See David Oxenford, A Deeper Dive into on the FCC's Ownership Order, BroadCASt Law Blog (Dec. 13, 2017), https://www.broadcastlawblog. com/2017/12/articles/a-deeper-dive-on-the-fccs-ownership-order/. The commissioner also approved standards for the next generation of high-definition televisions. See David Oxenford, FCC Approves Ownership Rule Changes and Next-Gen TV ATSC 3.0 Standard, BroadCast Law Blog (Nov. 17, 2017), https://www.broadcastlawblog.com/2017/11/articles/fcc-approves-ownership-rulechanges-and-next-gen-tv-atsc-3-0-standard/. 
However, Pai's most discussed and most controversial action was to repeal the so-called "net neutrality" rules, which were enacted to prevent unduly restrictive or discriminatory actions by Internet service providers ("ISPs"), who are primarily also telephone and cable television providers, to content services using those carriers. ${ }^{12}$ This policy change could have major implications for the dissemination of sports content that is streamed online. That is the focus of this article.

The FCC's repeal of net neutrality comes at a time of change in the way broadcast content, particularly sports content, is disseminated. For the purposes of this article, sports content includes live sporting events, pre-game and postgame shows, "sports talk" (primarily a radio format), blog or website commentaries, rebroadcasts of past sporting events, and increasingly, interactive sports, such as e-sports, fantasy sports (daily and season-wide), and sports gambling services. This content is transmitted to listeners and viewers in various platforms: traditional over the air broadcasting, cablecasting (which elbowed over-the-air broadcasting as the dominant content distributor and profit center in the 1980s), satellite services, mobile telephony, and, more recently and central to the issue at hand, broadband streaming.

The migration to broadband streaming as part of a stand-alone exclusive deal, or as part of a broadly packed "OTT" (over the top) arrangement involving various platforms is a reality and will likely play more prominence as many of the broadcast/cable rights deals with the major U.S. sports leagues conclude in the early 2020s. ${ }^{13}$ Although audiences for some sports have declined in recent years, sports events still command large blocks of viewers, and many observers think that rights fees can only increase as streaming becomes more viable. ${ }^{14} \mathrm{With}$ online power players such as Facebook, YouTube, Twitter, Amazon, and Netflix

\footnotetext{
12 See In the Matter of Restoring Internet Freedom, Declaratory Ruling, Report and Order, WC Docket No. 17-108, Dec. 17, 2017, (released on Jan. 4, 2018) discussed infra.

13 For example, the media rights deals between the Major League Baseball and Fox and ESPN expires in 2021; The National Football League's deal with Fox, CBS and NBC expires in 2022; the NBA's deal with ESPN/ABC expires in 2025; and the National Hockey League's deal with NBC Universal ends in 2020 and with Rogers Sports Net in Canada in 2025. See Mark Conrad, The BusINESS OF SPORTS (Routledge, 2017) pp 397-98.

14 See At the Gate and Beyond-Outlook for the Sports Market in North America through 2021. PWC REPORT (2017), https://www.pwc.com/us/en/industry/entertainment-media/publications/ assets/pwc-sports-outlook-2017.pdf ("The monetization of rights available in the nearer term-25 regional sports network ("RSN") deals across MLB, NBA and NHL will run-off within the next five years - as well as in at least the beginning of the next national rights deal cycle should remain strong given increasing competition for rights among traditional broadcast intermediaries and emerging distribution partners. There are also stronger paths to monetization across digital platforms in either rights form or direct subscription/ad-based models to the extent consumer engagement shifts from the linear broadcast”). See also, Anthony Cruppi, Sports Media Rights to Soar to \$23B in 2021, PWC Report Says. Advertising Age (Dec. 17, 2017) http://adage.com/article/ media/pwc-report-sports-m/311578/
} 
slowly but surely dipping their (large) toes into sports content, ${ }^{15}$ and with the possibility of Apple, Microsoft, and Verizon doing the same, we will see a very different landscape for sports broadcasting in the next half-decade. Significantly, mobile communications devices through their mobile apps, which have already secured some transmission rights over the last decade and a half, will likely be a larger medium for future distribution. ${ }^{16}$ Additionally, the increasing media merger activity, where one or more of the aforementioned will likely be involved, could hasten the convergence between content and distribution.

With this backdrop, questions abound regarding a net neutrality-less environment for sports. Could a major ISP "slow" the speed of an e-sports stream because the owners of the e-sports league refuse to pay an "additional access fee" for the fastest lanes of the broadband highway? Or, could a provider that owns its own cable sports channel "speed up" broadband transmissions of its own content? Or, could a provider "retaliate" against a blogger or website that is critical of a sports team that is streamed on its service? Given that a few states such as California enacted their own net neutrality laws, would they withstand a challenge from the federal government? While it is too early to say whether these scenarios will occur, the end of net neutrality creates the potential for these situations to take place. And that potential should make sports content providers nervous.

Part I of this paper consists of a short introduction into the legal basis and history of FCC regulation regarding common carriers. Part II gives a concise history of sports broadcasting, while Part III analyzes the FCC's "Net Neutrality Era," culminating with the December 2017 order abolishing net neutrality and the legislative and public reactions to that determination. Part IV discusses the

\footnotetext{
15 As of 2018, Facebook acquired live streaming rights in respect of Major League Baseball, the Mexican Liga MX, and Major League Soccer. Twitter broadcasts weekly Major League Baseball, NHL, and National League Lacrosse ("LCC") games in addition to live coverage of the WNBA and PGA Tour. It also has broadcast 17 e-sports tournaments. Amazon acquired two potential crown jewels: a number of Thursday Night Football games and a series of 40 matches over a three-year period from 2019-22. See Joe Lemire, Twitter's Value Proposition: Stream Sports with Curated Social Chatter, Sports Techie, Dec. 28, 2017, https://www.sporttechie.com/twitter-sports-streaming-social-conversation/; see also Mark Sweney, Amazon Breaks Premier League Hold of Sky and BT with Prime Streaming Deal, The Guardian (June 7, 2018), https://www. theguardian.com/media/2018/jun/07/amazon-breaks-premier-league-hold-of-sky-and-bt-withstreaming-deal?mod=djemCMOToday. YouTube, on its "YouTubeTV" portal, has secured rights to broadcast certain games from the MLS expansion franchise LAFC and the MLB Channel will be available within the next two years. See Robert Gray, YouTube TV Quickly Growing in Sports Sponsorship, Distribution, SportsBusiness Daily (April 19, 2018) https://www.sportsbusinessdaily.com/Daily/Issues/2018/04/19/World-Congress-of-Sports/YouTube-TV.aspx

16 Indeed, mobility rights can have a lucrative payday. The NFL's streaming contract with Verizon pays \$2 billion per year until 2023 and it covers fans a series of options besides traditional television for watching their local teams, as well as games on Sunday, Monday, and Thursday nights, even the playoffs and Super Bowl. See Kevin Draper, The NFL Goes Deep with Mobile and Verizon, The New York Times (Dec. 11, 2017) https://www.nytimes.com/2017/12/11/sports/football/nfl-verizon-digital-rights.html
} 
dangers to sports content by ISPs, citing hypothetical examples and any legal options for those who favor net neutrality and broadcast regulation. At the time of the completion of this article, it is difficult to come up with definitive answers: the goal is to discuss the issues and debate the legal and business options for sports content distributors.

\section{The Legal Basis and History of FCC Regulation Involving Common Carriers}

The Communications Act of $1934^{17}$ created the $\mathrm{FCC}^{18}$ and empowered it to license radio stations and establish technical (and even content) standards in radio broadcasting. ${ }^{19}$ Significantly, it also created a regulatory regimen for interstate telephone service, based on the idea that telephony is a "common carrier" rather than a content provider. Suffice it to say, common carriers have been subject to greater regulatory oversight, since First Amendment expression issues were not a primary concern for the telephone industry at the time of the legislation. ${ }^{20}$

When telephone service was limited to a wire communications service composed of millions of dial-up receivers, this distinction worked well. Because telephones and their lines were controlled by the American Telephone and Telegraph Company ("AT\&T") as a distributor of content, rather than a creator, the very

\footnotetext{
17 See Communications Act of 1934, ch. 652, 48 Stat. 1064.

18 See 47 USC $§ 151$

19 Id. at 47 USC $\S \S 303,307.319$ (construction permits), and 315 (the so-called "Equal Time"
} provision, which requires broadcast stations to give equal opportunities to opposing candidates). The FCC it replaced the Federal Radio Commission, which was created in 1927. Radio and, later, television were subject to more regulation than print (or later cable) mediums because broadcasters were required to operate "in the public interest, convenience and necessity," a lofty term that was not defined in the statute, but handed to the FCC, which issues and renews licenses to over the air radio and television broadcasters. See 47 USC $\S 309$. As part of this mandate, the FCC enacted the "fairness doctrine," which required broadcasters to air opposing views involving controversial issues of public importance; see Mark Conrad, The Demise of the Fairness Doctrine-A Blow for Citizen Access, 41 Fed. Comm. L. J. 161 (1988). This regulatory scheme was upheld by the Supreme Court as a valid exercise of governmental power based on the argument that airwaves are a "scarce" resource. See, e.g., NBC v. United States, 319 U.S. 190 (1943) ("Unlike other modes of expression, radio inherently is not available to all. That is its unique characteristic, and that is why, unlike other modes of expression, it is subject to governmental regulation. Because it cannot be used by all, some who wish to use it must be denied." Id. at 226); See also Red Lion Broadcasting v. FCC, 395 U.S. 367 (1969) ("In view of the scarcity of broadcast frequencies, the Government's role in allocating those frequencies, and the legitimate claims of those unable without governmental assistance to gain access to those frequencies for expression of their views, we hold the regulations and ruling at issue here are both authorized by statute and constitutional." Id. at 401).

20 See 47 USC $\S \S 201$ and 205. See also Douglas B. McFadden, Antitrust and Communications: Changes After the Telecommunications Act of 1996, 49 Fed. Comm. L. J. 457, 48 (1996) ("The 1934 Act gave the FCC power to control entry, regulate prices, and take whatever action was in the public interest including approving mergers and acquisitions. The FCC cooperated with the state commissions in following a jurisdictional separations policy between intrastate and interstate service and interconnection.") 
definition of a common carrier was fixed, by law and by circumstance. ${ }^{21}$ This business model was diametrically different from that of radio and television, which, by their nature, were developers and carriers of content. However, by the 1990s, this model was antiquated. During that time, the old AT\&T was divested into a number of regional carriers, plus a fully competitive long-distance arm. ${ }^{22}$ Congress, realizing a revolution in dissemination of data was going to disrupt existing technologies, enacted the Telecommunications Act of $1996 .{ }^{23}$ This law, the first major change in the communications laws in half a century, planted the seeds for a future regulatory distinction between "content providers" and "utilities" that became crucial in the net neutrality debate.

The 1996 Act, recognizing (or predicting) the different roles for what would be broadband Internet, crafted two different regulatory classifications. One was for "telecommunications carriers" and the other for "information-service providers." Resembling the mass media versus telephone company division at the time of the earlier Communications Act, the 1996 Act permits regulation of telecommunications carriers (but not information-service providers), as common carriers under Title II of the Act. ${ }^{24}$ Information-service providers, by contrast, are covered by Title I of the Act, and therefore not subject to the same regulatory discretion as the common carriers. Because of this, the distinction regulating such "Title I" services is more indirect, less encompassing, and consequently

\footnotetext{
21 AT\&T was a legal monopoly due to its common carrier status. In 1956, it was the dominant provider of telecommunications services in the U.S. and through its operating companies, it owned or controlled $98 \%$ of all the facilities providing long-distance telephone services and $85 \%$ of all facilities providing short-distance telephone services. These operating companies bought all of their equipment from Western Electric, the manufacturing subsidiary of AT\&T. The Department of Justice and the company entered into a consent decree that year that essentially kept the firm intact as long as it did not venture into any other non-telecommunications businesses. See Martin Watzinger, Thomas A. Fackler, Markus Nagler, \& Monika Schnitzer, How Antitrust Enforcement Can Spur Innovation: Bell Labs and the 1956 Consent Decree, working paper, Yale Economics Dept. (n.d.) Retrieved June 30, 2018, from https://economics.yale.edu/sites/default/ files/how_antitrust enforcement.pdf. See also U.S. v. Western Electric Co., Final Judgment, Civil Action No. 17-49 (D.N.J. Jan. 24, 1956)

22 See U.S. v. AT\&T, 552 F. Supp. 131 (D.D.C., 1982); see also, Andrew Pollock, AT\&T Breakup Opens Era of Great Expectations and Great Concerns, The New York Times (Jan. 1, 1984), https://www.nytimes.com/1984/01/01/us/bell-system-breakup-opens-era-of-great-expectationsand-great-concern.html. To settle an antitrust lawsuit, the firm was broken up into a competitive long-distance carrier (AT\&T) and the local operating arm became seven independently owned regional holding companies mainly engaged in providing local telephone service.

23110 Stat. 56 (1996)

24 The 1996 Act defines "telecommunications service" as "the offering of telecommunications for a fee directly to the public, or to such classes of users as to be effectively available directly to the public, regardless of the facilities used." 47 USC $\S 153(46)$ (2010). See National Cable and Telecommunications Ass’n v. Brand X Internet Services, 545 U.S. 967 (2005), citing 47 USC §§ 201-209.
} 
more difficult under the "ancillary jurisdiction" found under Title I of the 1996 $\mathrm{Act}^{25}$ In other words, the telecommunications service was akin to basic telephone service (albeit via broadband), and information service has added features (e.g., ready-made content) that makes it like cable television programmers. Hence, there are significant regulatory differences between a "Title II carrier" and a "Title I carrier."

The first broadband services were offered by cable companies seeking to expand their distribution as online Internet providers. Cable television (formally known as "multi-channel video programming distributors" or "MVPDs") was a relatively young medium from the 1950 s to the 1980 s and only became subject to direct FCC jurisdiction in $1984 .{ }^{26}$ However, many cable firms, because of their experience utilizing coaxial cable to send information, were uniquely positioned to enter the Internet broadband medium, in many cases serving as both programmers and distributors. Comcast is a good example. It is a distributor of content, whose cable lines are franchised in many communities, but is also a producer of content, especially as primary owner of the networks of NBC.

This posed a classification problem when cable services started offering broadband services. The question was how to regulate these services and if regulation would be warranted, what would be the basis of regulation - the easier "telecommunication service" standard of Title II or the more onerous "information services" standard of Title I of the Telecommunications Act. In 2005, the Supreme Court seemingly answered that question when it concluded that the FCC's determination of a what was then known as cable broadband (basically a cable modem system) fit under the less regulation-friendly "information service" category under Title I. Therefore, cable broadband firms did not have to share their infrastructure with other Internet information services. ${ }^{27}$

By the later years of the first decade of the 21st century, Internet distribution was dominated by a small group of firms with tremendous reach. Not only cable services like Cablevision, Comcast, and Charter/Spectrum (formerly

\footnotetext{
25 The 1996 Act defines "information service" as "the offering of a capability for generating, acquiring, storing, transforming, processing, retrieving, utilizing, or making available information via telecommunications, and includes electronic publishing, but does not include any use of any such capability for the management, control, or operation of a telecommunications system or the management of a telecommunications service." See 47 USC § 153(20) (2010). See also 47 USC $\S$ 151-161 as stated in Brand X, supra, 545 U.S. at 976.

26 Cable television has been regulated by the agency, albeit more recently and not in the same manner. Cable (then known as "community-access television") began as a reception-enhancement service for mainly rural, hard-to-reach areas for over-the-air signals. See Mark Conrad, The Saga of Cable's 'Must Carry' Rules, 10 PACE L. Rev. 9, 12 (1990) ("Early cable television systems began operations in the early $1950 \mathrm{~s}$, prompted by either the lack of quality reception in rural areas or the lack of local television outlets."). Before 1984, FCC regulation of cable was based on 47 USC § 154(i), the "ancillary jurisdiction" portion of the Communications Act, See U.S. v. Southwestern Cable, 392 U.S. 157 (1968). It was not until the Cable Communications Policy Act of 1984, where the FCC assumed direct jurisdiction over cable. See 28 Stat. 2779 (1984).

27 See Brand X, supra, n. 24. See also, Marguerite Reardon, FAQ: What Is Brand X Really About?, ZDNET (June 27, 2005), http://www.zdnet.com/article/faq-what-is-brand-x-really-about/
} 
Time-Warner Cable), but also landline/mobile telephony providers like Verizon and AT\&T (the descendant of an off-shoot of the once-ubiquitous Ma Bell) ${ }^{28}$ controlled the Internet broadband landscape. Not incidentally, the first three acquired rights to disseminate major sports content.

In controlling the "pipes" that funnel the content, the entities, now known as broadband Internet service providers ("ISPs"), have the power to slow or even shut down content. The potential for discrimination against content distributors - for economic, political, or any reason — has been addressed by a number of scholars. ${ }^{29}$ In fact, the term "net neutrality" was coined by Tim Wu at Columbia University as a regulatory remedy to prevent such discriminatory conduct by the providers against content producers that may not strike their fancy. ${ }^{30}$ It is this legacy that gave birth to the net neutrality era-and the regulatory sturm und drang $^{31}$ that has accompanied the regulatory saga.

\section{Sports and Broadcasting}

Sports have long been a mainstay of traditional broadcasters, and more recently, cable. In 1921, a boxing match became the first radio broadcast of a sporting event. $^{32}$ Less than two decades later, a college baseball game ushered sports

\footnotetext{
28 "Ma Bell" was a shorthand term referring to the pre-1984 AT\&T structure, an all-encompassing legal monopoly that contained Western Electric, AT\&T long distance, and 24 local Bell Operating Carriers ("BOCs"). Western Electric was the manufacturer, supplier, and installer of equipment; BOCs provided local and intrastate long-distance services; and AT\&T provided interstate long distance. See Aimee M. Adler, Competition in Telephony: Perception or Reality? Current Barriers to the Telecommunications Act of 1996, 7 J.L. \& PoL'y 571, N. 84 (citing Constantine Raymond Kraus \& Alfred W. Duerig, The Rape of Ma Bell 32 (1988). Top of Form.

29 Some scholars dismissed the need for a government-mandated non-discrimination requirement, arguing that the marketplace is best suited to deal with content issues. See, e.g., Ron Freiden, Assessing the Merits of Network Neutrality Obligations at Low, Medium and High Network Layers, 115 Penn ST. L. Rev. 49 (2010) (“Applying network neutrality principles to the vibrant application and content markets would endanger the open Internet because of the real potential for such regulations to stifle innovation, create disincentives for investment, and impose unnecessary operating costs."); for a contrasting view, see, e.g., Lawrence Lessig, The Future of Ideas: The Fate of the Commons in a Connected World 34-35 (2001) and Tim Wu, Network Neutrality, Broadband Discrimination, 2 J. of Telecommunications \& High Technology 141, 144 (2003). (" $\{$ t $\}$ he Internet community (and, at some point, regulators) should view with suspicion restrictions premised on inter-network criteria.")

30 Tim Wu, then a law professor at Columbia University, is created with coining the term. See Wu, n. 29

31 "Sturm und drang" is a German term that translates to "storm and stress." It denotes turmoil and the term was first used as the name of a late 18th century German literary movement characterized by works containing rousing action and high emotionalism that often deal with the individual's revolt against society. See MirRiam-Webster Dictionary, https://www.merriam-webster.com/dictionary/Sturm\%20und \%20Drang

32 The flight featured a 10-round boat between Johnny Ray and Johnny Dundee in Pittsburgh's Motor Square Garden broadcast on KDKA Pittsburgh. See KDKA Firsts (n.d.), http://pittsburgh. cbslocal.com/2010/04/01/kdka-firsts/
} 
broadcasting on television. ${ }^{33}$ Although sports events on cable television date from the late $1960 \mathrm{~s},{ }^{34}$ cable first developed as a reception-enhancement service for areas of the country that had difficulty receiving over-the-air broadcast signals. ${ }^{35}$ As the channel capacity of cable systems grew, they evolved into a programming service in addition to a reception-enhancement medium by the 1980s. For example, local stations became "superstations" and stand-alone cable-only services such as ESPN and CNN began to air in 1979 and 1980, respectively. ${ }^{36}$

Cable had an inherent economic advantage over traditional over-the-air broadcasts because radio and traditional television were limited to one source of revenue (advertising) and cable had two sources: the aforementioned advertising plus subscriber fees. That gave cable the ability to achieve profitability with smaller, more targeted audiences. Cable also needed more content. As a result, many sports migrated from broadcast (traditional over-the-air providers) to cable providers. Seeing the success of ESPN, regional sports networks have taken this model to a local level, resulting in many local team games shown exclusively (or nearly exclusively) on cable. ${ }^{37}$ Even today, sports content is king. ESPN charges providers the highest per-channel fees of any other service ${ }^{38}$ and those amounts have remained consistent even though cable penetration decreased by over 15 million households since 2013. ${ }^{39}$ Between over-the-air broadcasting, cable, and

\footnotetext{
33 That game was a match between the Columbia (University) Lions and the Princeton Tigers. See Sports and Television, ENCYClOPEDIA OF TELEVISION (n.d.), http://www.museum.tv/eotv/sportsandte. $\underline{\mathrm{htm}}$
}

34 For example, certain New York teams, like the Knicks and the Rangers, had their home games broadcast on cable systems in Manhattan in the late 1960s. See Fred Ferretti, TV Cable Company Signs 5-Year Pact for Garden Sports, The New York Times, (Nov. 1, 1970) p. 94.

35 See n. 26. supra.

36 ESPN began operations in 1979 under the name "Entertainment and Sports Network." In addition, local stations, known as "superstations" because they were carried on out of town cable providers, broadcast certain sports events. Atlanta-based WTBS-TV was one example. See 13 Strange Origin Stories of Your Favorite Cable Channels, ReAL CleAr.com (Feb. 2, 2016), http://www. realclear.com/tv/2016/02/02/origin_stories_of_cable_channels_12779.html\#ixzz5HGiBz5mx

37 For example, in New York, SportsNet New York ("SNY"), a joint venture owned by the Mets and Charter Spectrum Cable, carries Mets games. MSG Network was created to carry the Mets, Yankees, Knicks, and Rangers, respectively. See Josh Kosman \& Claire Atkinson, MSG Networks is Looking to Sell. New York Post (April 3, 2017), https://nypost.com/2017/04/03/msg-networks-islooking-to-sell/

38 In 2017, ESPN charged MVPDs \$7.21 just for ESPN, \$9.06 for ESPN's top networks (ESPN, ESPN2, ESPNU, SEC Network). See Clark Gaines, Cable and Satellite TV Customers Pay More than $\$ 9.00$ Per Month for ESPN Networks Whether they Watch them or not. BuSINESS INSIDER (March 7, 2017), http://www.businessinsider.com/cable-satellite-tv-sub-fees-espn-networks-2017-3

39 The number of cable or pay TV households peaked at 2013 at 113 million. In 2016 it dropped to 99 million and is predicted to drop further to 95 million by 2020. See Number of Pay TV Households in the United States from 2015 to 2020 (in millions). STatistica (n.d.), https://www.statista. com/statistics/251268/number-of-pay-tv-households-in-the-us/. 
satellite distributors, the professional and college sports rights in the U.S. and Canada comprised $\$ 20$ billion in annual rights fees in $2018 .{ }^{40}$

Although communications law and FCC policies tend to focus on technical and/or industry-wide issues, at times Congress has enacted sports-specific legislation and the FCC has targeted regulations aimed at sports broadcasting. One example is the Sports Broadcasting Act of 1961, which granted an antitrust exemption to the major professional sports leagues to negotiate unitary network broadcasting deals without the threat of antitrust litigation. ${ }^{41}$ After its passage, the NFL and other leagues were able to negotiate ever-increasing rights fees for such live programming. Freed from the potential of antitrust lawsuits by teams and others, the Act's immunity has had a major effect on the way sports broadcast rights are packaged and may have helped attain competitive balance. ${ }^{42}$

However, the cable model may be breaking down, as noted earlier, ${ }^{43}$ as more and more viewers are "cord-cutters" due to the high costs of monthly service. ${ }^{44}$ Broadband-only services such as Hulu, YouTube, Amazon, and Sling have tapped into this market and even ESPN launched a broadband-only service in $2018 .{ }^{45}$ In a few months after its launch, this service has topped one million subscribers. ${ }^{46}$ Hence, streaming has become a more important method of disseminating sports content, and will grow even more vital as many media rights agreements are expiring in the next five to seven years.

The NFL's TV deal with Fox, CBS, NBC, and ESPN lasts until 2021. Major League Baseball's broadcasting agreement with Fox, ESPN, and TBS ends the same year (but Fox' deal is extended to 2028), NASCAR runs through 2022,

\footnotetext{
40 See David Broughton, Media Rights, Labor Peace Push Industry to $\$ 69.3 B$. SPORTSBusiness DAILY (Dec. 11, 2017), https://www.sportsbusinessdaily.com/Journal/Issues/2017/12/11/Research-and-Ratings/PwC.aspx
}

41 See Sports Broadcasting Act of 1961, 75 Stat. 732, 15 USC § 1291 (1961) (which conferred an anti-trust exemption for network negotiated national television deals).

42 See Matthew Mitten \& Aaron Hernandez, The Sports Broadcasting Act of 1961: A Comparative Analysis of its Effects on Competitive Balance in the NFL and NCAA Division I FBS Football, 39 Оніо N. L. Rev. 745 (2014) ("Since the [Sports Broadcasting Act] was enacted, the NFL has collectively and exclusively sold all of its clubs' television rights and distributed the net revenues on a pro rata basis to each club. This form of horizontal revenue sharing among league clubs is positively correlated to a significant degree of on-field competitive balance among NFL clubs from 1962-2012.").

43 See n. 39, supra.

44 See Cable Prices Keep Going Up as More People Cut the Cord, New York Post (Jan. 5, 2018), https://nypost.com/2018/01/05/cable-tv-prices-keep-going-up-as-more-people-cut-the-cord/

45 See Daniel Roberts, YouTube and Amazon are Fighting for Sports Streaming Supremacy, YAноо SPORTS (Feb. 21, 2018), https://finance.yahoo.com/news/youtube-amazon-fighting-sports-streaming-supremacy-114738861.html

46 In just five months, ESPN+ signed over one million subscribers, surpassing industry expectations. In contrast, it took Hulu one year and four months to hit the one million mark. See Elaine Low, Disney Finally Reveals ESPN+ Subscriber Count-And It's Pretty Strong. Investors' BusINESS DAILY (Sept. 20, 2018), https://www.investors.com/news/espn-plus-subscribers-disney-1-mil$\underline{\text { lion/ }}$ 
the NBA is locked up until 2025, and the NHL's arrangement ends in 2021; the PGA Tour's CBS and NBC deals run through 2021; and the MLS's deal with ESPN and Fox last until 2022. The college football playoffs run through $2026 .{ }^{47}$ As noted earlier, many of these agreements already include some streaming, either from OTT rights or from packages to follow out-of-market games. The aforementioned extension of Fox Broadcasting's right to broadcast Major League Baseball includes expanded digital opportunities, including a deal with Facebook to disseminate 25 selected afternoon games during the 2018 season. ${ }^{48}$ The migration to streaming is sure to be more pronounced in the next generation of media rights packages. And a world of streamed content will involve a different conceptual mindset.

Traditional broadcast involves point-to-mass dissemination of information. ${ }^{49}$ Streaming offers different ways to disseminate the same content, but it's more like point-to-specified audiences - an audience of millions, thousands, or fewer, depending on the content and the interests of the audience. Because of the more flexible nature of Internet broadband, negotiating media rights deals opens many possibilities. It can be all-consuming (the aforementioned OTT), or sliced in different ways for numerous different platforms (e.g., national, regional, single event, game package, all-season). ${ }^{50}$ Despite drops in ratings in certain sports, the potential of the new power players - including Amazon, Netflix, Twitter, Facebook, and Google - and their market power and loaded budgets create the possibility of more revenues going to sports leagues, teams, and other entities ${ }^{51}$ not to mention newer creations, such as e-sports that are almost tailored-made for online streaming. Ultimately, it is streaming through broadband carriers that

\footnotetext{
47 See John Ourand, Deals Leave Big Rights Locked up for Now. SportsBusiness Journal (Oct. 13, 2014), https://www.sportsbusinessdaily.com/Journal/Issues/2014/10/13/Media/Next-media-rights. aspx. The extension of MLB's Fox deal includes more games and more digital broadcasts for a $\$ 5.1$ billion, considerably more than the $\$ 4.2$ billion in the expiring agreement. See James Wagner, M.L.B. Extends TV Deal With Fox Sports Through 2028, The New York Times (Nov. 16, 2018), https://www.nytimes.com/2018/11/15/sports/mlb-fox-tv-deal.html

48 See Scott Soshnick, Facebook Signs Exclusive Deal to Stream 25 MLB Games, BloomBerG (March 9, 2018), https://www.bloomberg.com/news/articles/2018-03-09/facebook-says-play-ballin-exclusive-deal-to-stream-25-mlb-games

49 Broadcasting was originally a farming term denoting the scattering of seeds across a wide area without a specific pattern. Later, radio communications appropriated that term as the radio's signal came from a single source and was received by many over a given area. See William A. Richter, Radio - A Complete Guide to the Industry (Peter Lang, Inc., 2006), p. 2.

50 See Manali Kulkarni \& Sean Cottrell, Key Sports Law Cases of 2017, Law In Sports (Jan., 2017), https://www.lawinsport.com/topics/articles/item/key-sports-law-cases-of-2017-usa?category id=112.

${ }^{51}$ Id. The authors note succinctly, "[W]ith Amazon reportedly paying the NFL five times more than Twitter spent last year for streaming rights[,] [t]he bidding wars will only intensify as the previously finite pool of traditional rights market has been replaced by a broader mix of distribution possibilities, while the market itself is also contracting. Cord shavers, cord cutters, and cord-nevers have fundamentally reduced traditional TV viewership and have fragmented among the seemingly endless options for OTT streams. Meanwhile, the list of distributors has grown beyond major networks to include new streaming platforms, social media, online retailers, and even teams and leagues themselves. As distributors negotiate for new rights opportunities against more rivals, they are also battling for smaller segments of a smaller market."
} 
may well be the future of sports content deals, and the way it is distributed could be affected by the FCC net neutrality policy.

\section{Net Neutrality-Birth, Challenge, Survival, and Death}

The impetus that led to the era of enforced net neutrality began with an action that many feared could happen: Comcast, a major broadband ISP slowed (or "throttled") certain traffic on its broadband system. It did so against "bit torrent" services $^{52}$ on the ground that these services (which often serve as a way for subscribers to impermissibly download copyrighted information) were affecting the overall traffic of the service. ${ }^{53}$ While few in the industry will defend the merits of bit torrents, fears that throttling could apply to other content served as a justification for the need for a net neutrality rule. This coincided with the appointment by President Barack Obama of Julius Genachowski, who was a staunch net neutrality advocate, to chair the FCC. ${ }^{54}$

\section{A. The First Two Attempts}

The first attempt to mandate a net neutrality regimen came in 2009, when the FCC approved what was known as the "Open Internet Order." 55 This order centered on a policy of preventing broadband providers from acting in a discriminatory manner with regard to lawful content. ${ }^{56}$ Stripped to its essentials, the order protected the creators and disseminators of content (called "edge providers" in administrative parlance) that generate the content through the pipes of the broadband ISPs from

\footnotetext{
52 BitTorrent enables people to swap large files more efficiently amongst each other than with traditional file transferring programs. It does so by breaking the file into a multitude of small pieces that can be downloaded separately from many different people at the same time. It became an effective method for downloading of media files containing movies and TV shows, as well as files containing pirated software, which are often hundreds of megabytes. See Rhys Boyd-Farrell, Legal Analysis of the Implications of MGM v. Grogster, 11 Intell. Prop. L. Bull. 77, 78 (2006).

53 See Peter Svensson, Comcast Blocks Some Internet Contact, Wash. Post (Oct. 19, 2007), http:// www.washingtonpost.com/wpdyn/content/article/2007/10/19/AR2007101900842_pf.html [[http:// perma.cc/EWG3-A7M7], cited in David Terrian, Justice Scalia: Liberal Lion? An Examination of Chevron Deference, Net Neutrality, and Possible Outcomes of a Supreme Court Decision on The Federal Communication Commission's Open Internet Order, 17 Tex. Tech. Admin. L. J. 233, 264 (2016).

54 See Thessaly La Force, A Conversation: Julius Genachowski on Net Neutrality. The New YorkER (Sept. 23, 2009), https://www.newyorker.com/news/news-desk/conversation-julius-genachowski-on-net-neutrality

55 See In the Matter of Preserving the Open Internet, 4 FCC RCD. 13064 (F.C.C.), 24 F.C.C.R. 13064 (2009). The Commission defined "broadband providers" as a service that "provide[s] the capability to transmit data to and receive data from all or substantially all Internet endpoints." See In the Matter of Preserving the Open Internet, 25 FCC RCD. 17905, 17932 (2010)

56 The order, among other proposals, would require a broadband Internet access service provider to treat lawful content, applications, and services in a nondiscriminatory manner. $I d$. at 13067 .
} 
being muzzled or slowed by those very providers ${ }^{57}$ The edge providers generally supported net neutrality because they did not want the service providers to slow their traffic or take other actions that affect the distribution of their content. However, their support has not always been uniform, especially if they dominate that particular type of content. ${ }^{58}$

The ink was hardly dry when the Open Internet Order was challenged in the D.C. Circuit Court of Appeals, which ultimately struck down the order because the panel concluded that the FCC lacked the legislative authority to issue it. ${ }^{59}$ The court in Comcast v. FCC focused on a 2002 FCC decision classifying broadband as an "information" service (a determination upheld by the Supreme Court in Brand $X$ discussed earlier). As a de facto non-utility, the FCC was constrained to find a method to regulate net neutrality through the indirect "ancillary jurisdiction" method, which it could not do.$^{60}$ Basically, the court determined that since the FCC could not cite any direct or reasonably direct statutory authority to do what it did, the Open Internet Order did not pass muster.

On the heels of that ruling, the FCC tried again later that year, issuing a second order, known as the "Open Internet Rules." The order proposed similar "no blocking" and "no discrimination" standards involving broadband service providers as well as a "transparency" requirement where the providers would disclose "accurate information" about their performance and terms of service. ${ }^{62}$ Because of its more recent vintage, "mobile broadband" would not be subject to as many rules as more "traditional" online distribution.

Looking for a stronger statutory hook, the Commission cited Section 706(a) of the 1996 Telecommunications Act as the regulatory foundation, as it authorizes the Commission "to take actions that encourage the deployment of advanced

\footnotetext{
57 An "edge provider" is defined as any individual or entity that provides any content, application, or service over the Internet, and any individual or entity that provides a device used for accessing any content, application, or service over the Internet. See David Post, Does the FCC Really Not Get It About the Internet?, THE WASHINGTON Post (October 31, 2014), https://www.washingtonpost.com/ news/volokh-conspiracy/wp/2014/10/31/does-the-fcc-really-not-get-it-about-the-internet/?noredirect $=$ on\&utm term $=.994 \mathrm{ed} 1 \mathrm{e} 7330 \mathrm{a}$

58 See Ray Sylvestor, The Concerned Citizen's Guide to Net Neutrality, Hyperlink Magazine (Nov. 17, 2017), https://medium.com/hyperlink-mag/the-concerned-citizens-guide-to-net-neutrality-16901d212b15

59 See Comcast v. FCC, 600 F.3d 642 (D.C. Cir. 2010).

${ }^{60}$ The panel concluded that since the FCC in 2002 concluded that broadband ISPs were neither "telecommunications services" nor "cable services" (e.g., utility-based), there was far less leeway to impose the net neutrality under the current proposal. The attempt by the FCC to cobble together past Supreme Court rulings on cable TV content regulation was not enough to justify this regulation, rejecting arguments that sections 4(i) of the 1934 Communications Act and 706 of the 1996 Telecommunications Act confer such jurisdiction. See 47 USC 154(i); 47 USC 1302(a). See Comcast, 660 F. 3d at 645-46; 658-59.

${ }_{61}$ See In the Matter of Preserving the Open Internet, 25 FCC RCD. 17905 (2010) ("The Open Internet Rules").

62 Id. at 17943-44.
} 
services" using its existing rulemaking powers. ${ }^{63}$ In other words, the FCC relied on a general catch-all provision. Not surprisingly, another major ISP, Verizon, challenged the order, and once again, the D.C. Circuit voided it, but in doing so, left a door open for the FCC to pursue a pared-down net neutrality scheme. ${ }^{64}$

The court accepted the rationale for regulating Internet traffic through broadband service providers, noting that it was "reasonably interpreted" and "supported by substantial evidence." The court added that the FCC's concerns about blockage and discrimination against certain edge providers were legitimate and justifiable. ${ }^{65}$ The opinion added that if Title II of the Telecommunications Act designated the broadband ISPs as telecommunications services, then the agency very well may have that authority. ${ }^{66}$ However, it concluded that the Commission's classification of these service providers as Title I carriers precludes this justification. ${ }^{67}$ In other words, the ill-fated choice to designate broadband service providers as information services back in 2002 came back to haunt the FCC once again.

\section{B. The Third and Successful Attempt to Enact Net Neutrality}

Taking the cues from the court, FCC chair Tom Wheeler proposed a weakened net neutrality standard that was able to satisfy the court's objections. And the majority of the FCC did it by doing what it should have done earlierreclassifying broadband ISPs as a "utility" under Title II of the 1996 Act, rather than the heretofore utilized "information service" under Title I. ${ }^{68}$ This time, the Commission adopted what it considered "carefully-tailored rules" that would prevent specific practices we know are harmful to Internet openness, such as the three noted in the earlier attempts to impose net neutrality-outright blocking of content, slowing of transmissions, and the creation of so-called "fast lanes" for users that pay an extra fee. ${ }^{69}$ The rules also included mobile telephony into this standard.$^{70}$ According to the majority of the FCC, the basis for reclassifying

\footnotetext{
${ }^{63}$ See 47 USC $\S 1302$ (A) ("The Commission ... shall encourage the deployment on a reasonable and timely basis of advanced telecommunications capability to all Americans ... by utilizing ... price cap regulation, regulatory forbearance, measures that promote competition in the local telecommunications market, or other regulating methods that remove barriers to infrastructure investment."), noted in Comcast, 600 F3d at 668.

64 See Verizon v. FCC, 740 F. 3D 623 (DC Cir. 2014).

${ }^{65} I d$. at 645 ("the Commission has adequately supported and explained its conclusion that, absent rules such as those set forth in the Open Internet Order, broadband providers represent a threat to Internet openness and could act in ways that would ultimately inhibit the speed and extent of future broadband deployment. First, nothing in the record gives us any reason to doubt the Commission's determination that broadband providers may be motivated to discriminate against and among edge providers.")

66 Id.

67 Id.

${ }^{6}$ See In the Matter of Protecting and Promoting the Open Internet, 30 FCC RcD. 5601 (2015).

69 These included practices known as "blocking, throttling, and paid prioritization." Id. at 5604. See also Jeff Sommer, What Net Neutrality Rules Say, The New York Times (March 12, 2015), https://www.nytimes.com/interactive/2015/03/12/technology/net-neutrality-rules-explained.html

70 Id. at 5615 .
} 
providers as Title II utilities was centered on the "tremendous" public support for net neutrality and the need for a "light touch" regulation under a " $21^{\text {st }}$ Century Title II."71 In explaining the rationale for making this categorical change, the Commission opined that "so much has changed" since the 2002 Brand X determination of Title I status, that a reappraisal of broadband service a decade and a half later justifies the reclassification as a Title II utility. ${ }^{72}$

The industry challenged these rules once again, but this time the FCC won. The D.C. Circuit in U.S. Telecom Assn v. FCC concluded that the FCC acted reasonably when it reclassified broadband service as a telecommunications service with de facto utility status under Title II and gave valid reasons for that reclassification. ${ }^{73}$ The panel did not question the FCC's justifications to make the change in classification, under the general standard of court deference to administrative determinations. ${ }^{74}$ It thereby concluded that the justifications for the reclassifications were not arbitrary and capricious and did not violate any statutory prohibitions. ${ }^{75}$

\section{The 2017 Net Neutrality Order}

As discussed in the introduction of this paper, the Trump Administration had very different ideas about net neutrality and the newly constituted FCC began crafting its repeal. In early 2018, a sharply divided Commission released its antinet neutrality order (known by the lofty title "Restoring Internet Freedom") 76 and its intent was made clear as the majority reversed the Obama FCC's "heavyhanded utility-style regulation of broadband Internet access service and return to the light-touch framework." 77 The majority opted to restore Internet broadband's classification as an "information" service (the non-utility) under Title I of the 1996 Telecommunications Act as opposed to the more heavily regulated, utility-based "telecommunications service" under Title II of the Telecommunications Act. ${ }^{78}$

\footnotetext{
$71 \quad I d$. at 5607,5613 .

72 Id. at 5615 ("today, broadband providers are offering standalone transmission capacity ... The trajectory of technology in the decade since the Brand $X$ decision has been towards greater and greater modularity ... Today, broadband internet access service is fundamentally understood by customers as a transmission platform through which consumers can access third-party content, applications, and services of their choosing.")

73 825 F.3D 674 (D.C. Cir. 2016).

74 Id. at 697. See also Chevron U.S.A., Inc. v. Natural Resources Defense Council, Inc., 467 U.S. 837 (1984) (courts must be deferential to administrative agency interpretation of statutes, unless Congress has specifically addressed that statutory interpretation).

75 Id. at 713. The court also spent much time on the technical issues regarding the mobile telephone aspect of the rules. As this discussion is not directly relevant to the point of the article (and is astoundingly complex), I omitted discussion of this issue.

76 See 33 FCC RCD. 311 (Jan. 4, 2018). It was approved by a 3-2 vote with Chairman Pai, and commissioners Carr and O'Rielly approving. There were fierce dissents from commissioners Clyburn and Rosenworcel.

77 Id. at 312.

78 Id.
} 
The 500-plus page ruling makes for heavy reading, focusing on administrative law, judicial doctrine, and economic assumptions. The Commission majority concluded that economic theory, empirical studies, and observational evidence support reclassification of broadband Internet access service as an "information service" rather than a public utility, thereby mandating little or no regulation. ${ }^{79}$ It touted the advantages of what it called a "light touch" approach by stressing the economic boost the reclassification will have in terms of ISP investment. ${ }^{80}$ In other words, the more regulation, the less innovation. The report added that if a broadband ISP blocks websites and fails to notify the public, this deceptive practice can be sanctioned by the Federal Trade Commission ("FTC"), as that agency has jurisdiction over deceptive trade practices and consumer fraud. ${ }^{81}$ Under the guise of 'transparency,' they opined that the enforcement of a market-based approach, with the FTC as the best 'police' of 'Internet Freedom,' would come at a 'lower social cost' than the regulatory Title II categorization. Such enforcement could provide for additional innovation and investment that will facilitate greater consumer access to more content, services, and devices, and greater competition. ${ }^{82}$ In addition, the majority suggested that antitrust laws can be utilized for actions that restrain trade..$^{83}$

To be fair, these arguments have some merit, but commentators have noted that consumer deception and antitrust have greater hurdles for aggrieved consumers than FCC powers. ${ }^{84}$ In particular, the time and cost of pursuing an antitrust case would be prohibitive and the legal difficulties to determine issues

\footnotetext{
$79 \quad I d$. at 395 .

80 Id. at 369, citing economic studies by Ford and in support of this conclusion. See George S.
} Ford, A Further Review of the Internet Association's Empirical Study on Network Neutrality and Investment, Phoenix Center Perspectives 17-10 (Aug. 14, 2017). See also Thomas W. Hazlett \& Joshua D. Wright, The Effect of Regulation on Broadband Markets: Evaluating the Empirical Evidence in the FCC's 2015 'Open Internet' Order, 50 Rev. Indus. Org. 487, 499 (2017), as cited in n. 349 and n. 360 , respectively.

${ }^{81}$ Id. at 394 ("The FTC also requires the "disclos[ur]e [of] material information if not disclosing it would mislead the consumer," so if an ISP "failed to disclose blocking, throttling, or other practices that would matter to a reasonable consumer, the FTC's deception authority would apply." [citations omitted]

${ }^{82}$ Id. at 434-435 ("[W] c conclude that preexisting federal protections - alongside the transparency rule we adopt today - are not only sufficient to protect Internet freedom, but will do so more effectively and at lower social cost than the Title II Order's conduct rules. In short, we believe the light-touch framework we adopt today will pave the way for additional innovation and investment that will facilitate greater consumer access to more content, services, and devices, and greater competition.”)

83 Id. at 447 ("we conclude that the oversight over ISPs' practices that the Commission, FTC, and other antitrust and consumer protection authorities can exercise as a result of the transparency rule likewise will promote innovation and competition, spreading the benefits of technological development to the American people broadly.")

84 See Amar Naik \& Brittany Walker, Is Antitrust Law a Viable Substitute for Net Neutrality?, Antitrust Law Blog (June 7, 2017), https://www.antitrustlawblog.com/2017/06/articles/antitrust/ antitrust-law-net-neutrality/ ("As a practical matter, antitrust litigation is often costly, time-consuming, and untimely (i.e., relief may come "too late" after the conduct has happened"). 
like a "relevant market" and "unreasonable" agreement to restrain trade make the antitrust field one of the most demanding and difficult areas to pursue. ${ }^{85}$

In their repeal of the net neutrality rules, Chairman Pai and the two Republican commissioners concluded that they were "ineffective" and "would distort the market with a patchwork of non-uniform, limited purpose rules." 86 Rejecting the need for rules that prevented paid prioritization, blocking, and throttling, ${ }^{87}$ the Commission determined that the "few instances" of blocking by ISPs do not justify such government regulation. It added that the many stakeholders involved in producing, distributing, and viewing the content would not tolerate such blocking. During times when it was not required, providers have "voluntarily abided by no-block practices," further adding to its defense of deregulation. ${ }^{88}$

The majority's conclusion produced two blistering dissents. Commissioner Mignon Clyburn called the repeal the "Destroying Internet Freedom Order." After noting that the majority ruling did not adequately consider the millions of comments - many from consumers against the proposed scrapping of the rulesClyburn painted a dark picture of the potential for abuse based on well-heeled providers engaging in paid prioritization. ${ }^{90}$ Commissioner Jessica Rosenworcel echoed these concerns in her dissenting statement, when she criticized the naiveté of the majority for thinking that the broadband providers would graciously not engage in throttling, paid prioritization, or discrimination.

"This is not good. Not good for consumers. Not good for businesses. Not good for anyone who connects and creates online. Not good for the democratizing force that depends on openness to thrive. Moreover, it is not good for American leadership on the global stage of our new and complex digital world." 91

\footnotetext{
85 See Terrell McSweeney, The FCC Plans to Kill the Open Internet; Don't Count on the FTC to Save It, QuARTZ Media (Dec. 5, 2017), https://qz.com/1144994/the-fcc-plans-to-kill-the-open-internet-dont-count-on-the-ftc-to-save-it/ ("[L]et's say that the FTC has jurisdiction and legal authority to mount a challenge. (Already, we are making a number of rosy enforcement assumptions.) It might take years before the agency could get a court order halting the practice. During that time, the dominant ISP could continue to discriminate against its rival, potentially driving it out of business.")

${ }^{86}$ See Restoring Internet Freedom, 33 FCC RCD. 311 at p. 140.

87 Id. at 450 .

${ }^{88} I d$. at 468 ("Stakeholders from across the Internet ecosystem oppose the blocking and throttling of lawful content, including ISPs [citations omitted], public interest groups [citations omitted], edge providers [citations omitted], other content producers [citations omitted], network equipment manufacturers [citations omitted], government entities [citations omitted] and other businesses and individuals who use the Internet [citations omitted]").

89 Id. at 533 (Dissenting Statement of Commissioner Clyburn).

$90 \quad I d$.

${ }^{91} I d$. at 355. (Dissenting Statement of Commissioner Rosenworcel)
} 
The only consolation for those in favor of regulation was a requirement that the broadband ISPs disclose to users how they handle web traffic without the restrictions of net neutrality. ${ }^{92}$

Since the repeal order, the media world has become more complex. With merger activity in the media industry drawing more alliances between content providers and broadband ISPs, the quaint 1990s world of small websites and chat forums dominating the Internet is long gone. In 2018, a federal judge concluded that there were no antitrust concerns in the proposed merger of AT\&T, a leading distributor via satellite (DirectTV) and mobile, and Time-Warner, a leading content provider (including sports-oriented programming such as the NCAA basketball tournament). The two companies were free to join with no restraints. ${ }^{93}$ Shortly afterwards, Disney (owner of ABC and ESPN) outbid Comcast to purchase the content library of 21 st Century Fox. ${ }^{94}$ While the antitrust issues behind these complex deals are the subject of a different article, it is safe to say that some media giants are getting bigger. ${ }^{95}$

The net neutrality repeal went into effect on June 11, 2018. Well before the effective date, the FCC's order was challenged by a number of states and public interest groups ${ }^{96}$ and a few states have passed or considered legislation

\footnotetext{
92 Id. at 313
}

93 See U.S. v. AT\&T, 310 F. Supp. 3d 161 (D.D.C., 2018) ("The Government here has taken its best shot to block the merger based on the law and facts, and within the time allowed. The defendants did their best to oppose it. The Court has spoken. To use a stay to accomplish indirectly what could not be done directly-especially when it would cause certain irreparable harm to the defendantssimply would be unjust."). 310 F. Supp. 3d at 253-54.

94 See Cynthia Littleton, Justice Department Approves Disney's Acquisition of 21st Century Fox with Divestiture of Regional Sports Networks, VARIETy (June 27, 2018), https://variety.com/2018/ biz/news/disney-21st-century-fox-justice-department-approval-1202859241/. As part of that $\$ 71.3$ billion transaction, Disney has agreed to sell off 21st Century Fox's 22 regional sports networks.

95 For a trenchant analysis of the shifting media trends and antitrust, see James Stewart, AT\&TTime-Warner Decision Shows Need to Rethink Antitrust Laws, The New York Times (June 13, 2018), https://www.nytimes.com/2018/06/13/business/att-time-warner-antitrust-stewart.html?hp\&action $=$ click\&pgtype $=$ Homepage \&clickSource $=$ story-heading \&module $=$ first-column-region\&region=top-news\&WT.nav=top-news

96 Within a month after the adoption of the rules, 22 state attorneys general filed a petition to the U.S. Court of Appeals for the District of Columbia Circuit, claiming the FCC's rollback was "arbitrary and capricious," and a reversal of the agency's longstanding policy to prevent ISPs from blocking or charging websites for faster delivery of content to consumers. See State of New York et al. v. FCC, No. 18-1030, (filed Jan. 16, 2018). Mozilla, which runs the Firefox web browser, and the Open Technology Institute also filed suit on similar grounds. See also Mozilla Corp. v. FCC, No. 18-1030 (filed Jan. 16, 2018); Cecilia King, Flurry of Lawsuits Filed to Fight Repeal of Net Neutrality, The New York Times (Jan. 16, 2018), https://www.nytimes.com/2018/01/16/technology/ net-neutrality-lawsuit-attorneys-general.html 
overturning the order, ${ }^{97}$ including California, which adopted the strictest and most far-reaching reimposition of net neutrality. ${ }^{98} \mathrm{~A}$ few others have done so by executive order. ${ }^{99}$ As of this writing, the FCC's order was highly unpopular with many in Congress (mostly Democrats), and the Senate passed a bill that would have reinstituted the prior net neutrality scheme. However, it is unlikely to pass the House and even so, it lacks support from the White House. ${ }^{100}$ The deregulatory order has been challenged in court, ${ }^{101}$ but as of early 2019 , no rulings have been made.

The California law is a broad-based reintroduction of net neutrality. It applies to broadband ISPs that provide services to customers in California. ${ }^{102}$ Like the FCC's former rule, it outlaws the blocking or throttling of access to websites, but it goes further. It bans a recent practice known as "zero rating," where mobile telephone providers stream content they favor without counting it against consumers' data usage. ${ }^{103}$ This practice gives the mobile providers a strong incentive to favor their own content over that of competitors. ${ }^{104}$ Such a law, along with the somewhat less sweeping laws from other states, raise significant constitutional and pre-emption questions, such as whether the law violates the commerce clause or whether it is a proper exercise of state sovereignty. The federal government compellingly demonstrated its objections when the Department of Justice filed suit against California within an hour after the California law was signed. Not surprisingly, Pai criticized the legislation, stating that provision banning zero

\footnotetext{
97 As of August 27, 2018, legislators in 30 states have introduced over 72 bills requiring ISPs to ensure various net neutrality principles. In 13 states and the District of Columbia, legislators introduced 23 resolutions primarily expressing opposition to the FCC's repeal of net neutrality rules; urging the U.S. Congress enact legislation reinstating and requiring the preservation of net neutrality; or stating the chamber's support of general net neutrality principles. Legislation was passed in Oregon, Washington and Vermont reinstating net neutrality. See Net Neutrality Legislation in States, National Conference of State Legislators (August 27, 2018), http://www.ncsl.org/research/ telecommunications-and-information-technology/net-neutrality-legislation-in-states.aspx

98 See CA Senate Bill S.B. 822 (signed Sept. 30, 2018).

99 Id. As of August 27, , Governors in six states-Hawaii, New Jersey, New York, Montana, Rhode Island, and Vermont - have signed executive orders. The California legislature passed a net neutrality bill, which was signed by Gov. Jerry Brown.

100 See Mallory Locklear, Net Neutrality Still Faces an Uphill Battle in Congress, Engadget (May 16, 2018), https://www.engadget.com/2018/05/16/net-neutrality-faces-uphill-battle-in-congress/. See also Cody Fenwick, Net Neutrality Under President Trump; 5 Things to Know, White House PATch (Nov. 22, 2017), https://patch.com/us/white-house/net-neutrality-under-president-trump-5things-know

101 See n. 94.

102 See CA Senate Bill S.B. 822, sec. 3100(b).

103 See Alejandro Lazo \& John D. McKinnon, Trump Administration Sues Over California Net Neutrality Law, The Wall Street Journal (Oct. 1, 2018), https://www.wsj.com/articles/california-enacts-net-neutrality-in-defiance-of-trump-administration-1538355513

104 See Alejandro Lazo \& John D. McKinnon, California Advances Net-Neutrality Rules in Rebuke to Trump FCC, The Wall Street Journal (Aug. 30, 2018), https://www.wsj.com/articles/ california-advances-net-neutrality-rules-in-rebuke-to-trump-fcc-1535669946? mod=article inline
} 
rating will hurt users, especially those of lower incomes. ${ }^{105}$ Although California has agreed to delay enforcement of its new law, pending the result of the Justice Department's lawsuit, ${ }^{106}$ the conflict between the California law and the FCC policy will likely result in protracted litigation, and will cause confusion for broadband ISPs, content programmers, and consumers. As we will see later, sports content will very much be affected.

\section{The Potential Effects of a No-Net Neutrality World on Sports Content}

Assuming that the net neutrality deregulatory order remains in place, the potential effects on sports online programming through broadband ISPs - whether live events, recorded content, or commentaries - could be significant. Throttling, paid prioritization, or discrimination issues may result. Possibilities include "slowing" disfavored sports content or charging sports providers for access to the faster lanes in the pipeline. The following hypothetical scenarios demonstrate the potential real-life effects. While it seems less likely for providers to deliberately slow down content from major sports events like NFL games, due to adverse fan reaction, there are possibilities involving other sports - traditional and newlyminted. This paper outlines a number of hypothetical scenarios that are possible.

\section{Hypothetical No. 1. Broadband Provider v. Cable Channel- Slowing the Traffic}

Broadband Internet service provider X owns the Soccer Channel. The Soccer Channel has exclusive rights to stream games from the top league in Spain. It also carries on its system the World Football Channel (owned by Y), which has the license to stream games from the top French league. Since games on both channels often occur at the same time (as Spain and France are in the same time zones), there is a conflict in scheduling. Because of this direct conflict, Provider $\mathrm{X}$ decides to stream the Spanish games on the fastest broadband possible, while relegating the games from the French league on a "slower lane" than the Soccer Channel, resulting in less clear reception. When the World Football Channel complains, Provider X offers to put those games on the same high speeds, but demands extra compensation for doing so.

The World Football Channel refuses, and then Provider X decides to eliminate the rival service because the dispute became so acrimonious. Without a net neutrality scheme, it would be far more difficult to legally stop this action. Although claims of antitrust could be made, the difficulties noted earlier would make it much less of an effective remedy for the users adversely affected. But the FCC's hands would be tied, making it unable to properly enforce this policy.

\footnotetext{
105 See n. 101. Pai claimed that the California would be particularly painful for consumers, those free data plans help consumers save money on their mobile bills.

106 See Jon Brodskin, Net Neutrality Delay: Calif. Agrees to Suspend Law Until After Court Case, Ars Technica (Oct. 26, 2018), https://arstechnica.com/tech-policy/2018/10/california-delays-net-neutrality-laws-enforcement-until-after-court-case/
} 
It is easy to see how a heavy-handed cable multi-channel video programming distributor (MVPD) could use its broadband in this manner.

\section{Hypothetical No. 2. Baseball Slowdown}

The Ames Avalanche broadcasts the great majority of its games on the Avalanche Sports Net, a regional sports network (RSN) owned by the team. Alpha Cable is also the MVPD in the county where the team is located and where the great majority of its fans live. Alpha Cable also offers broadband service, where it carries the Avalanche Sports Net on both its cable systems and online. However, Omega Telephone, a local telephone and wireless carrier, plans to offer an alternative Internet broadband service. In a quest for more subscribers, it purchases the RSN from the team, a purchase that clears regulatory hurdles since the Department of Justice concluded that it does not pose antitrust problems.

One year later, with Omega Telephone's streaming service in full operation, there is intense competition between these companies for subscribers. Omega Telephone, the owner of the Avalanche's RSN, refuses to allow Alpha Cable to stream Avalanche games (although it does allow the games on its cable system) unless Alpha Cable pays a rights fee of 50\% above the prior amount, which would increase the price paid by subscribers. However, subscribers to Omega Telephone's service can view Avalanche games for no additional charge. Under net neutrality, such an arrangement could be a discriminatory attempt to penalize customers of Alpha Cable (and put Alpha Cable in a less competitive position). But those Alpha subscribers have little recourse, except putting up with it or changing the broadband carrier to Omega Telephone.

\section{Hypothetical No. 3. The Nasty Website}

Beta Cable owns the Philadelphia Knights, a professional hockey team. A website is created by disgruntled Knights fans lamenting the lack of success of the team and criticizing the team's general manager, coaches, players, and even the broadcast announcers. The website draws many fans that enjoy reading the daily rants by the creators of the website and the responses by many fans. Often, the commentary is nasty and personal. Sometimes, it is based on false conclusions.

Executives of Beta Cable and the team are monitoring the website. One morning, a feature on the website titled "The Knights Players Do Not Come to Play_-They Party Every Second Night!" The article makes claims, based on an anonymous source, that "certain players" engage in illicit sex, sometimes with minors. No players are specifically named. Because proving defamation would be difficult based on the lack of specific player names and the players' public figure status ${ }^{107}$ Beta Cable decides to block the website. Could the provider censor the site? Without net neutrality, it is very likely.

\footnotetext{
107 In order to prove defamation, the statement must be a false statement of fact, must be "of and concerning" the plaintiff(s) and in the case of a public figure, must be shown to be done with malice or reckless indifference to its truth. See New York Times v. Sullivan, 376 U.S. 254 (1964).
} 


\section{Hypothetical No. 4. Sports Talk Radio}

This scenario involves a similar situation to the previous case. Let's say that WSPO, an AM sports talk radio station, is streamed by Gamma Broadband, the dominant broadband ISP in the Ames County area. The morning hosts at WSPO, Cain and Abel, incessantly criticize the Ames Bears, a team owned by Gamma Broadband. Fed up with the constant criticism, Gamma decides to take this program off the stream. Without net neutrality, that move would be permissible.

\section{Hypothetical No. 5. The E-sports Conundrum}

Perhaps one of the most problematic results of the end of net neutrality lies in the burgeoning field of e-sports. E-sports games require large amounts of data, especially with the advent of $4 \mathrm{~K}$ and HDR visuals. ${ }^{108}$ The e-sports industry has been growing in popularity and primarily relies on the Internet for streaming multiplayer competitions.

E-sports games are particularly dependent on the size and speed of the bandwidth offered by ISPs. So, if an ISP decides to enforce "fast lanes" and data caps on players, it would threaten the competitive integrity of online video games. ${ }^{109}$ A world with net neutrality would restrict the providers from imposing special charges for these sites or throttling them if they do not pay more. But a net neutrality-less environment gives the providers the power to impose whatever extra fees they want. Examples could be a "high bandwidth fee" for subscribers to access e-sports games privately or as part of a competition ${ }^{110}$ so that users can access networks like Xbox Live, PlayStation Network, or Steam. The pricing could be variable, so that certain gamers who pay more can get more (read: faster) bandwidth. But to be fair, this could also be seen as an opportunity for gamers to choose which levels of bandwidth service they wish, and to create a market based on speed and price. If done in good faith, the ISPs can monetize this large use of data.

But there is a potential economic downside. Nothing can stop the providers from charging fees (maybe even hefty fees) for enhanced service on a

\footnotetext{
108 See Jarren Ginsburg, Ryan Lowry, Raymond Luk Jr., \& Kadmiel Perez, Game Over for Net Neutrality: Esports in a Deregulated Internet, E-SPORTS OBSERVER (Jan. 18, 2018), https://esportsobserver.com/game-over-for-net-neutrality-esports/. A $4 \mathrm{~K}$ computer monitor is a level of display resolution based on a number of pixels. $4 \mathrm{~K}$ monitors have a display resolution of 3840 pixels. This is about four times as many pixels as a typical high-definition television, which has 1080 pixels. For more information, see Chris Hoffman, Should you Buy a 4 K Computer Monitor?, How to GeEK (Jan. 4, 2016), https://www.howtogeek.com/206710/should-you-buy-a-4k-computer-monitor/. An HDR, or high dynamic range, expands the range of both contrast and color significantly on a television screen. Bright parts of the image can get much brighter, so the image seems to have more "depth." Colors get expanded to show more bright blues, greens, reds, and everything in between. See Geoffrey Morrison, What is HDR for TVs, and why Should You Care?, CNET (March 27, 2017), https://www.cnet.com/news/what-is-hdr-for-tvs-and-why-should-you-care/.

109 See Lawrence Zhao, Net Negative: What the Repeal of Net Neutrality Means for Esports. BEAR Bites: The Daily Californian Sports Blog (Jan. 21, 2018), http://www.dailycal.org/2018/01/21/ repeal-net-neutrality-means-esports/

110 See Ginsburg, n. 98.
} 
"superhighway." However, that could result in either: (1) the e-gaming service passing the costs to the users, creating an adverse reaction by those gamers, who tend to be younger and may revolt against paying extra for these services; or (2) eating those costs in an effort to keep gamers from deserting the service, making it difficult for new services to compete if they do not want to pay extra or pass those costs and have to utilize "slower" bandwidth services.

In addition, a ban on net neutrality can have consequences for future development plans for e-gaming. As a graphics-focused business, there is the need for constant improvement of graphics interfaces that may propel the need for greater bandwidth - and the potential for more lines of paid prioritization.

\section{Hypothetical No. 6. Bloggers Delight}

Babbling Bob is a blogger who likes to criticize major media conglomerates. He has particular scorn for Charter/Spectrum cable, which offers cable and broadband service in parts of New York City and Los Angeles, among other areas. In 2013, what is now Charter/Spectrum paid $\$ 8.35$ billion over 25 years to create a "Dodgers" channel and have exclusive rights to broadcast Los Angeles Dodgers games. ${ }^{111}$ Charter/Spectrum only has about one-third of the market wired, so it would negotiate retransmission fees with the other cable carriers in the market for cable and broadband transmissions of the games. The other carriers refused to accept Charter/Spectrum's terms and, as a result, the majority of Angelenos cannot access these Dodgers games for the last five years. ${ }^{112}$

Babbling Bob's blog has focused on this situation. He blogs daily with a plea to "call up Charter Spectrum cable and give it a piece of your mind. Don't back down." He also says, in the same daily exhortation, "for those of you who are Charter/Spectrum subscribers, please stop. You can now get ESPN Stream and other services."

After 18 months of these daily blogs, Charter/Spectrum blocked this blog on its broadband service. No reason is given. As it is a private entity, there is no First Amendment protection against an ISP taking such an action. ${ }^{113}$ Potentially, there could be an antitrust question, if the entity conspired to restrain trade by agreement (highly unlikely since for purposes of this hypothetical, it acted alone), ${ }^{114}$ or by abusing its monopoly powers (assuming that it has such market control and if

\footnotetext{
111 See Bill Shaikin, Now in its Fourth Season, There Is No End to Dodgers' TV Blackout, Los Angeles Times (July 17, 2017), http://www.latimes.com/sports/mlb/la-sp-dodgers-tv-shaikin20170617-story.html

112 Id.

113 The First Amendment applies only to state actors, and broadband ISPs are not state actors, but private firms. See Daniel Lyons, The First Amendment Red Herring in the Net Neutrality Debate, Forbes (March 10, 2017), https://www.forbes.com/sites/washingtonbytes/2017/03/10/the-firstamendment-red-herring-in-the-net-neutrality-debate/\#56531b12326a. See also Lloyd Corp. v. Tanner, 407 U.S. 551(1972) (privately owned shopping center, not a state actor for First Amendment purposes).

114 See Sherman Act, 15 USC $\S 1$ (illegal for two or more to enter contracts that unreasonably restrain trade).
} 
so, assuming the blogger has the legal resources to undertake such litigation). ${ }^{115}$ But if net neutrality rules were in effect, such an action would almost certainly violate the prohibition on content discrimination.

\section{Hypothetical No. 7. The Politics of Sports}

While the intersection of politics and sports is hardly new, recent eventsparticularly involving civil rights and police brutality claims by AfricanAmericans and other people of color-have brought athlete activism to the forefront of the media. Former San Francisco 49ers quarterback Colin Kaepernick demonstrated his feelings by "taking a knee" during the playing of the national anthem. ${ }^{116}$ The action was replicated by a number of players from NFL teams and was unpopular among many fans, including President Trump, who became a catalyst for more protests when he castigated the players in question at a rally in $2017 .{ }^{117}$ Ultimately, the NFL owners, without the input from the players, approved a compromise. ${ }^{118}$

Let's say that Kaepernick decides to make on-air appearances to explain his actions. He appears on ESPN and other sports networks. Could the White House attempt to put subtle pressure on broadband providers to either black out any of his appearances or to slow down the signal? This would be a fascinating First Amendment issue on the question of whether state action exists. ${ }^{119}$ However, that is a theoretical question that would not have to be resolved if net neutrality existed, since it would prohibit that kind of conduct.

\footnotetext{
115 Id., $\S 2$ (illegal to engage in monopolistic conduct in a given trade),

116 "I am not going to stand up to show pride in a flag for a country that oppresses black people, and people of color," Kaepernick said in a press conference after first sitting out during the anthem. "To me, this is bigger than football, and it would be selfish on my part to look the other way. There are bodies in the street, and people getting paid leave, and getting away with murder." See Clark Mindock, Taking a Knee: Why Are NFL Players Protesting and When Did They Start to Kneel?, The IndePendent (UK) (May 24, 2018), https://www.independent.co.uk/news/world/ americas/us-politics/taking-a-knee-national-anthem-nfl-trump-why-meaning-origins-racism-uscolin-kaepernick-a7966961.html

${ }^{117}$ Id. At a rally in Alabama, the President said, "Wouldn't you love to see one of these NFL owners, when somebody disrespects our flag, to say, 'Get that son of a bitch off the field right now, out, he's fired. He's fired.' ... You know, some owner is going to do that. He's going to say, 'That guy that disrespects our flag, he's fired.' And that owner, they don't know it [but] they'll be the most popular person in this country."

118 Id. NFL owners unanimously approved a new national anthem policy requiring players to stand if they are on the field during the performance of the song. Players have the option to remain in the locker room during the anthem if they prefer.

119 See Marc Edelman, Standing to Kneel: Analyzing NFL Players' Freedom to Protest During the Playing of the U.S. National Anthem, 86 Fordham L. Rev. Online 1 (2018).
} 


\section{Hypothetical No. 8. Be Careful What You Wish For? Sports Gambling in a Net Neutrality-less Environment}

After the Supreme Court's 2018 ruling declaring a federal ban on sports gambling unconstitutional, ${ }^{120}$ the possibility of online gambling services will become more likely as more and more states legalize betting schemes. ${ }^{121}$ The prospect of online betting could provide an advantageous environment for both gaming firms and service providers without net neutrality. ${ }^{122}$ Gaming companies (which would likely include daily fantasy sports firms expanding into this business) have the capital to absorb costs for any fees the providers would charge for faster speeds that would enhance the online betting process. This would be a case where the needs of the market - coupled with the cash required-could benefit many. Some commentators predict that broadband ISPs could start offering gambling packages targeted to certain kinds of real-time betting. ${ }^{123}$ In addition, with a transition to a faster $5 \mathrm{G}$ standard for cellular phones, the possibilities for carriers to have the broadband capacity and speed to handle massive betting becomes very real. ${ }^{124}$

Admittedly, this scenario would enhance the best aspects of a deregulated market, and a strengthened net neutrality regime could pose problems with this reality. Say that the broadband provider has an ownership interest in one gaming firm and gives it a faster lane than others. Verizon, which owns Yahoo Sports, could serve as an example. What if Verizon, on its Fios service, prioritizes its service, which has a sports betting service for users in the states that have legalized sports gambling. This would result in a situation of prioritizing its own content, which would place other competing firms at a disadvantage.

\footnotetext{
120 See Murphy v. NCAA ___ U.S. ___ (May 14, 2018). The court invalidated the 1992 Professional and Amateur Sports Protection Act, 28 USC § 3071, et seq., concluding that it violated the anti-commandeering doctrine and was therefore unconstitutional as a violation of state sovereignty. 121 By the summer of 2018, six states have legalized sports betting. At least one state, New Jersey, has allowed online betting in the state. At this time, there is a question as to whether interstate online betting is legal because of the prohibitions outline in the Interstate Wire Act of 1961, 18 U.S.C. $§ 1084$ (prohibiting the use of a wire communications facility for the transmission in interstate or foreign commerce of bets or wagers or information assisting in the placing of bets or wagers on any sporting event or contest) and the Unlawful Internet Enforcement Gaming Enforcement Act of 2006 ("UIGEA"), 31 USC $§ 5361$ et seq. (prohibiting payment processors from knowingly accepting payments in connection with online gambling).

122 See Kelsey Griffis, Net Neutrality Sunset Could Boost Online Sports Betting, Law360.com (June 6, 2018), https://www.law360.com/articles/1050257/net-neutrality-sunset-could-boost-online-sports-betting

123 Id.

124 See Mike Dano, Editor's Corner-Real-Time, High-Speed Sports Betting Is the Best Use Case for $5 G$, Fierce Wireless (June 1, 2018), https://www.fiercewireless.com/5g/editor-s-corner-realtime-high-speed-sports-betting-best-use-case-for- $5 \mathrm{~g}$
} 


\section{Hypothetical Number 9. A New Media Environment}

As noted earlier, media consolidations are going to affect the communications landscape significantly in the next few years. With the merger of AT\&T and Time Warner, Disney's acquisition of the assets of 21st Century Fox, the uncertainty of whether CBS and Viacom will merge, and the distinct possibility of Google or Amazon purchasing a more traditional media company, some commentators have said that the environment is the death of the Internet as we know it. ${ }^{125}$

With less oversight - due to the lack of net neutrality and the generally permissive standards for allowing vertical combinations in the first place ${ }^{126}$ - these uber-powerhouses can impose programming decisions that could adversely affect smaller competitors. In a peculiar twist, one author proposes a reinstatement of common carrier rules to deal with Amazon's market power (ironically, the approach rejected by the FCC regarding net neutrality). ${ }^{127}$

With AT\&T acquiring Time Warner's media properties - which include HBO, CNN, TBS, TNT, and Cartoon Network in addition to DirecTV (the satellite broadcasting service) - the combined firm has the power to block or slow down competing content in favor of its own content. Or, it could utilize a paid prioritization system requiring payments for content on the fast lane. Given the considerable sports content involved - boxing (Showtime), NCAA men's basketball (Turner), Major League Baseball (Fox/ESPN/Turner), and the possibility of expanding its roster of sports rights to include primetime NFL coverage and college football - this is not an idle concern. As of the beginning of 2019, AT\&T, with its deep financial pockets, may well expand its stable of sports rights. As one commentator noted, "the size of the new AT\&T would give it an advantage over traditional media companies. Imagine a company that could pick up rights covering linear TV, digital, over-the-top, mobile and pay-per-view all in one bid."128

A Disney acquisition of the vast content of 21st Century Fox poses greater

\footnotetext{
125 See T. C. Sottek, Net Neutrality Is Dead. It Is Time to Fear Mickey House, The Verge (Dec. 14, 2017), https://www.theverge.com/2017/12/14/16776298/net-neutrality-disney-comcast-internet-providers-free-speech; see also Todd Tandeski, Digital Download: IHOB, Mega Mergers, and the Death of Net Neutrality, Lessing Flynn Digital Download (June 15, 2018), https://www. lessingflynn.com/digital-download-ihob-mega-mergers-death-net-neutrality/

126 See Lina Khan, Amazon's Antitrust Paradox, 126 YALE L. J. 710 (2016) (“'[C]urrent doctrine underappreciates the risk of predatory pricing and how [vertical] integration across distinct business lines may prove anticompetitive. These concerns are heightened in the context of online platforms for two reasons. First, the economics of platform markets create incentives for a company to pursue growth over profits, a strategy that investors have rewarded.")

127 Id. at 797

128 See John Ourand, Expect Larger AT\&T to be a Significant Player in Sports Rights, SPORTSBusINESS JourNAL (June 25, 2018), https://www.sportsbusinessdaily.com/Journal/Issues/2018/06/25/ Media/Sports-Media.aspx
} 
issues, but they are alleviated with the sale of the 22 RSNs formally owned by Fox. ${ }^{129}$ Neither deal included FS1, Fox's national sports network. ${ }^{130}$

To be fair, there has been no attempt or intent to engage in throttling, discrimination, or paid prioritization and each of these hypotheticals are fictional scenarios. These events are so recent that it may take some time to see how the landscape evolves. Also, Chairman Pai and the two other FCC commissioners did not preclude all enforcement - they wanted to defer to the FTC, which would consider anti-competitive aspects of these activities and whether those activities violate antitrust law. While that may sound acceptable in theory, antitrust enforcement is a long, expensive, and complex business, which can take years of investigation and litigation. It would be difficult to consider this a viable alternate to net neutrality.

\section{Hypothetical 10. State Attempt to Impose Net Neutrality}

As noted earlier, at least California and three other states have enacted their own version of net neutrality since the FCC's repeal. If those state laws survive legal challenge, a confusing dichotomy of net neutrality states (dominated by California) and non-net neutrality states would exist, posing challenges for any broadband ISP that would attempt to engage in any throttling or other content discrimination. With this in mind, what would happen if a provider took action to slow down or eliminate any sports-related programming that would be seen in California? Given its size and population, this law could result in many ISPs being subject to its jurisdiction if they provide service to California residents.

\section{Conclusion}

Sports broadcasting is in transition. The migration to broadband streaming from traditional over-the-air broadcast or cable means that streaming options controlled by ISPs will achieve considerable dominance and market power. That means the service providers that control those highways will possess the power as to how to disseminate content - both content owned by them and owned by others that may be their competitors. The goal behind a net neutrality requirement is to create an equal playing field for all content providers, akin to the arrangement of a traditional utility. It serves as a fairness watchdog guarding against potentially discriminatory actions by the broadband operators - a sort of 21st Century "public interest" standard. With the demise of net neutrality and the likelihood of its reimposition by a future Congress or an FCC slim, the providers can call the shots unless the court invalidate the FCC's deregulation

\footnotetext{
129 The antitrust issues resulted from the Disney acquisition were not insignificant. If Disney were to keep the RSNs, it would have over $80 \%$ control of the sports cable market. If Comcast was successful in the purchase instead of Disney, it would dominate the more specific RSN market, since it controls nine RSNs, For more background, see Erich Schwartzel \& Joe Flint, Disney, Comcast Bids for Fox Assets Could Face Regulatory Sticking Point: Sports, Wall Street Journal (June 14, 2018), https://www.wsj.com/articles/disney-comcast-bids-for-fox-assets-could-face-regulatory-sticking-point-sports-1529017087?mod=itp\&mod=djemITP $h$

130 Id.
} 
order. The attempt by states such as California to reimpose net neutrality will result in confusion and inconsistency - not to mention prolonged litigation on the question of state power and federal pre-emption. Coupled with the increase in sports content online, the potential of large broadband ISPs controlling content, speed, and priority of such programming could have major ramifications for sports providers and consumers. 